Article

\title{
Occurrence of Selected Known or Suspected Endocrine-Disrupting Pesticides in Portuguese Surface Waters Using SPME-GC-IT/MS
}

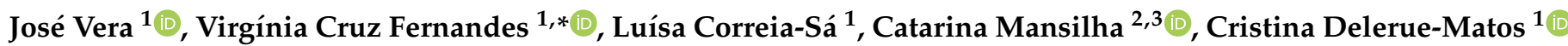 \\ and Valentina F. Domingues ${ }^{1}$ D \\ 1 REQUIMTE/LAQV, Instituto Superior de Engenharia do Porto, Instituto Politécnico do Porto, \\ Rua Dr. António Bernardino de Almeida 431, 4200-072 Porto, Portugal; jlquifi.2@gmail.com (J.V.); \\ mariacs31@gmail.com (L.C.-S.); cmm@isep.ipp.pt (C.D.-M.); vfd@isep.ipp.pt (V.F.D.) \\ 2 REQUIMTE/LAQV, University of Porto, Porto, Praça Gomes Teixeira, Apartado 55142, \\ 4051-401 Porto, Portugal; catarina.mansilha@insa.min-saude.pt \\ 3 Instituto Nacional de Saúde Doutor Ricardo Jorge, R. Alexandre Herculano 321, 4000-055 Porto, Portugal \\ * Correspondence: vircru@gmail.com or virginiacruz@graq.isep.ipp.pt; Tel.: +35-12-2834-0500
}

check for updates

Citation: Vera, J.; Fernandes, V.C.; Correia-Sá, L.; Mansilha, C.;

Delerue-Matos, C.; Domingues, V.F

Occurrence of Selected Known or Suspected Endocrine-Disrupting Pesticides in Portuguese Surface Waters Using SPME-GC-IT/MS. Separations 2021, 8, 81. https:// doi.org/10.3390/separations8060081

Academic Editor: Alena Kubatova

Received: 21 April 2021

Accepted: 1 June 2021

Published: 7 June 2021

Publisher's Note: MDPI stays neutral with regard to jurisdictional claims in published maps and institutional affiliations.

Copyright: (c) 2021 by the authors. Licensee MDPI, Basel, Switzerland. This article is an open access article distributed under the terms and conditions of the Creative Commons Attribution (CC BY) license (https:/ / creativecommons.org/licenses/by/ $4.0 /)$.

\begin{abstract}
A multiresidue analytical methodology based on a solid-phase microextraction (SPME), followed by gas chromatography-ion trap mass spectrometry (GC-IT/MS), has been developed for trace analysis of 20 known or suspected endocrine-disrupting pesticides. The SPME conditions are optimized considering several key parameters to obtain the maximum sensitivity. After the optimization, the method validation is performed, and the limits of detection (ranged from 2-150 ng/L) and the coefficient of determination (above 0.990) of studied compounds are determined for all the analytes. A robust sampling of twenty sampling points of surface water samples from the north and center of Portugal is performed, and the validated methodology is applied. In total, 20 compounds from four chemical families (13 organochlorine, 1 organophosphorus, 2 dicarboximide, and 4 pyrethroids) are studied, and the pesticides most frequently detected are eight organochlorine pesticides $(\alpha-, \beta-\mathrm{HCHs}$, lindane, HCB, o, $p^{\prime}$-DDT, $p, p^{\prime}$-DDE, $p, p^{\prime}$-DDD, $\alpha$-endosulfan), cypermethrin, and vinclozolin.
\end{abstract}

Keywords: gas chromatography; monitoring; endocrine-disrupting pesticides; Portugal; solid-phase microextraction; surface waters

\section{Introduction}

The term endocrine-disruptors have been generally used to call compounds with characteristics in common, namely, with the capability to mimic the actions of hormones interfering with the behavior of endocrine systems in various living species [1]. The endocrine-disruptors compounds (EDCs) can be different chemical groups, such as pesticides, pharmaceuticals, and personal care products, polybrominated diphenyl ethers, among others [2]. Most of these are released to the environment by anthropogenic activities and may coexist and accumulate in crops and human bodies through food chains, posing risks to human health and the ecosystem [3,4]. Endocrine-disrupting pesticides (EDPs) are the largest group of EDCs. Despite all the benefits related to pesticide application (e.g., control of pests and diseases), they still can contaminate different environmental compartments being the aquatic environment the most vulnerable because of massive global use and its consequent degradation products $[5,6]$. The industry introduced several synthetic pesticides, such as organochlorine pesticides (OCs) (1940s), organophosphorus (OPs) (1960s), carbamates (1970s), and pyrethroids (PYR) (1980s). OCs, many of them classified as EDPs, were banned or restricted after the 1970s in most countries of the world, but continuously detected until today, due to their characteristics, such as high lipophilicity, bioaccumulation, high persistence, and potential of long-range transport [7]. The other chemical families of pesticides (e.g., OPs, carbamates, and PYR) are placed on the market 
as alternatives to OCs, and they are described as being less persistent, but more acutely toxic to control insect pests [8,9]. Studies have reported that chronic low-level exposure to OPs in the uterus and childhood are associated with poorer cognitive and behavioral problems [10]. PYR are also reported as lipophilic compounds, accumulate in sediments, bioaccumulated in biota [11], and neurotoxic [12,13]. In fact, national and international governments established programs and legislation to assess chemical safety regarding their potential to interact with the endocrine system of humans and wildlife, and considerable efforts have been made regarding ECPs control levels in waters. European Union (EU) collected data about EDPs, and priority lists are defined [14]. In terms of water analysis, maximum allowable concentration-Environmental Quality Standards (MAC-EQS) based on the directive 2013/39/EU [15], and the drinking water 98/83/EC [16] directive are strictly consulted and discussed. Due to the low levels of pesticides in the environment, ranging from $\mathrm{ppb}$ to $\mathrm{ppt}$, and the complexity of the environmental matrices, the preconcentration of the samples before the analysis is usually required. One of the analytical techniques reported for isolation and preconcentration of pesticides from water samples is solid-phase microextraction (SPME) [17-19]. It is based on the sorption of analytes directly from the sample in one-step extraction and preconcentration of analytes $[18,20]$. The SPME has demonstrated its simplicity, usefulness, selectivity, and efficiency in the analysis of a broad range of compounds in several matrixes without requiring sample pretreatment [21].

Filho et al. [22] reported a multiclass residues analysis by GC-MS after SPME in twenty-six water samples from Brazil. Recently SPME was tested successfully for sixteen water samples from the North of Lebanon and the results obtained indicate a potential risk of environmental contamination and the need to perform seasonal monitoring [23].

Contamination, due to multiclass pesticides, has been reported in different countries, indeed recently, e.g., in surface water samples [24], and sediments [25]. In Portugal, several studies about the presence of these priority pesticides, resulting from the different sources, were reported in food [26,27], soils [28], sediments [29-32], marine samples [33], rivers waters [34-38], and Small Public Water Supply Systems [39]. Despite the resulting contamination from the last decades, there are only a few studies on the quantification and monitoring of known and suspected EDPs in Portuguese surface water samples.

The present study aimed to: (i) Select sampling sites focus on areas considered susceptible to be contaminated, namely, with intense urbanization, agricultural and industrial sites; (ii) develop an SPME coupled with GC-IT/MS for analyzing known and suspected EDPs in surface waters; (iii) apply the methodology in twenty surface water samples located in the north and center of Portugal; (iv) assess the river samples quality for twenty pesticides (OCs, OPs, dicarboximide, and PYR).

\section{Materials and Methods}

\subsection{Reagents, Solvents, and Materials}

The pesticide characteristics (e.g., chemistry groups, company supplier, chemical structure, and molar mass) are presented in Table S1 (Supplementary Material). Methanol was supplied by Sigma Aldrich (Steinheim, Germany), and n-hexane was purchased from Merck (Darmstadt, Germany). Both solvents with purity over 99\%. Glacial acetic acid was obtained from Carlo Erba (Val de Reuil, France), and sodium hydroxide p.a. grade was purchased from Pronolab (Saint Paul, MN, USA). Individual stock solutions of each standard $\left(\alpha-, \beta\right.$-HCHs, lindane, HCB, $o, p^{\prime}$-DDT, $p, p^{\prime}$-DDE, $p, p^{\prime}$-DDD, aldrin, dieldrin, endrin, $\alpha$-and $\beta$-endosulfan, methoxychlor, bifenthrin, cypermethrin, deltamethrin, diazinon, fenvalerate, iprodione, and vinclozolin) were prepared in n-hexane in the $100 \mu \mathrm{g} / \mathrm{L}$ concentration and stored at $-18{ }^{\circ} \mathrm{C}$. The work standard mixture containing the twenty pesticides was prepared by dilution in n-hexane of the stock solutions up to a concentration of $5 \mu \mathrm{g} / \mathrm{L}$.

Ultrapure water (resistivity of $18.2 \mathrm{M} \Omega . \mathrm{cm}$ ) was produced using a Simplicity 185 system (Millipore, Molsheim, France). All weight measurements were done on an analytical balance, Metter Toledo (Columbus, OH, USA), and the $\mathrm{pH}$ adjustment was measured in a GLP 22 pH meter supplied by Crison (Barcelona, Spain). 


\subsection{Site Selection and Sampling}

Twenty spot samples from ten rivers (Douro, Cávado, Lima, Minho, Sousa, Tâmega, Leça, Cabrum, Caima, and Ave), one lagoon (Ria de Aveiro), and one stream (Moscoso) located in the north and center of Portugal were collected from 20 different sampling points. A global position system (GPS) was used to locate the sampling points (Figure 1). Samples were collected in precleaned amber glass bottles $(250 \mathrm{~mL})$, previously rinsed several times with the surface water, acidified with glacial acetic acid $(1 \%, v / v)$ immediately after collection, and stored at $4{ }^{\circ} \mathrm{C}$. Samples were processed in $24 \mathrm{~h}$. The samples were collected during the spring (April) and summer (June) seasons.

\subsection{Description of the Surface Water Samples (Rivers, Lagoon, and Stream)}

The Douro is one of the longest rivers in the Iberian Peninsula, sharing its $930 \mathrm{~km}$ with Spain and Portugal [40]. The Douro River samples were representative of an urban area. Sousa, Cabrum, and Tâmega Rivers are tributaries of Douro River. The Leça River has its estuary near the port of Leixões. Chemical and bacteriological quality data led to classify the Leça River water quality as "bad" or "very bad" [41]. The Leça River is from the urban and industrial areas. The Minho River extends over $300 \mathrm{~km}$ in a southwest direction in the northwest corner of the Iberian Peninsula. Its terminal $70 \mathrm{~km}$ constitutes the natural border between Portugal and Spain, including the main estuarine axis of approximately $40 \mathrm{~km}$ (upstream limit of springtides) [42,43]. The Lima River estuary is an urban-industrialized estuary; the input of agricultural runoff impacts this system and urban and industrial sewage, which discharges nutrients and other substances that are transported from domestic, industrial, and agricultural areas into the estuarine area [44]. The Cávado River is in north Portugal. It runs $135 \mathrm{~km}$ from Gouveia to its mouth next to the city of Esposende. The Ave River basin is in a very populated region of the country. River water is intensively used for agricultural and industrial purposes, namely, textile industries [45]. Ria de Aveiro coastal lagoon is an estuarine system on the northwest coast of Portugal [46]. It is a shallow system that occupies an area of $43 \mathrm{~km}^{2}$ at low tide. The Moscoso Stream and Caima River are tributaries from Ria de Aveiro estuarine zone. The Caima River drains a catchment area of about $196 \mathrm{~km}^{2}$, in the north-center region of Portugal [47]. These samples were from the urban, agricultural, and industrial areas.

\subsection{Extraction Procedure}

\subsubsection{Conditioning and Cleaning Procedure}

The SPME (100 $\mu \mathrm{m}$ Polydimethylsiloxane (PDMS) fiber) procedure was performed with a manual fiber holder assembly supplied by Supelco (Darmstadt, Germany). A magnetic stirring and heater unit (AGIMATIC-N, Mundilab) was used during the SPME procedure. According to factory recommendations, the PDMS fiber used in the present study was conditioned at $250{ }^{\circ} \mathrm{C}$ in a current of helium for one hour in the GC-MS injector (Supelco ${ }^{\circledR}$ ). Routinely, the conditioning was achieved by exposing the fibers to the injector port at $260^{\circ} \mathrm{C}$ for $30 \mathrm{~min}$ before use. Fiber blanks were performed to ensure that no interferences from the fibers were present in GC chromatograms. After thermic desorption of the analytes in the GC, the fiber remained in the injector for several minutes for further cleaning at a high temperature. The liner in GC-MS was also replaced and cleaned every week to prevent the accumulation of analytes, and thus, unwanted peaks in the chromatograms.

\subsubsection{Sample Enrichment}

Standard water samples were prepared by spiking ultrapure water with a mixture of pesticides (5000 ng/L of the twenty pesticides) to validate the SPME step. Atrazine D-5 was used as an internal standard at $5000 \mathrm{ng} / \mathrm{L}$. The comparison between studies with ultrapure water and a surface water sample (residue-free) was conducted to evaluate the SPME efficiency. 

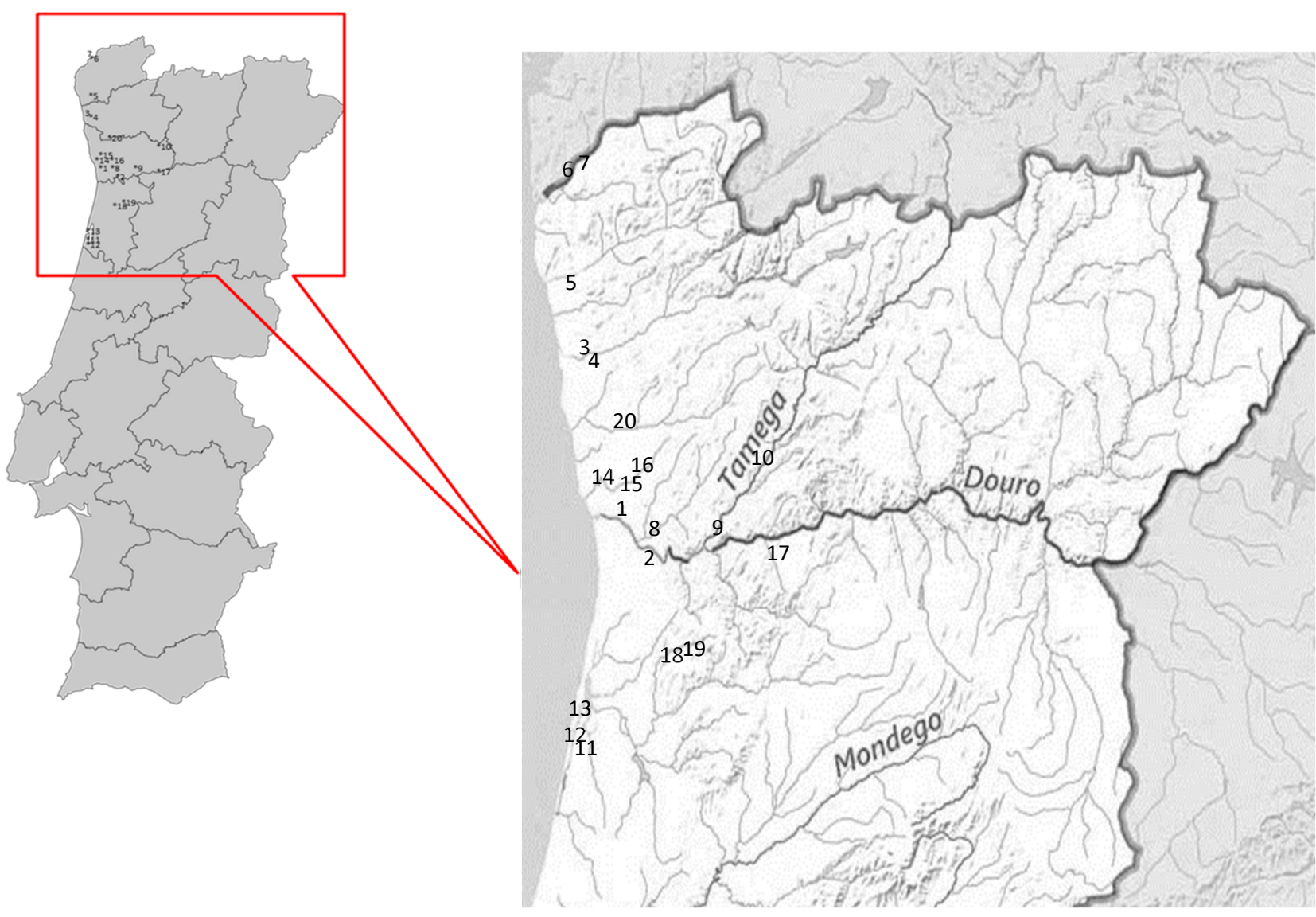

\begin{tabular}{|c|c|c|c|c|}
\hline Sample & Type of Surface Water & Coordinates & Sampling Point, City & District \\
\hline 1 & \multirow{2}{*}{ Douro River } & $41^{\circ} 8^{\prime} 36^{\prime \prime} \mathrm{N} ; 8^{\circ} 38^{\prime} 53^{\prime \prime} \mathrm{W}$ & Afurada & Porto \\
\hline 2 & & $41^{\circ} 4^{\prime} 20^{\prime \prime} \mathrm{N} ; 8^{\circ} 29^{\prime} 10^{\prime \prime} \mathrm{W}$ & Lever, V.N. Gaia & Porto \\
\hline 3 & \multirow{2}{*}{ Cávado River } & $41^{\circ} 30^{\prime} 54^{\prime \prime} \mathrm{N} ; 8^{\circ} 46^{\prime} 12^{\prime \prime} \mathrm{W}$ & \multirow{2}{*}{ Braga } & \multirow{2}{*}{ Braga } \\
\hline 4 & & $41^{\circ} 31^{\prime 2} 2^{\prime \prime} \mathrm{N} ; 8^{\circ} 46^{\prime} 17^{\prime \prime} \mathrm{W}$ & & \\
\hline 5 & Lima River & $41^{\circ} 41^{\prime} 57^{\prime \prime} \mathrm{N} ; 8^{\circ} \mathrm{D}^{\prime} 36^{\prime \prime} \mathrm{W}$ & Viana do Castelo & Viana do Castelo \\
\hline 6 & \multirow{2}{*}{ Minho River } & $41^{\circ} 56^{\prime} 28^{\prime \prime} \mathrm{N} ; 8^{\circ} 44^{\prime} 47^{\prime \prime} \mathrm{W}$ & Cerveira & Viana do Castelo \\
\hline 7 & & $41^{\circ} 56^{\prime} 27^{\prime \prime} \mathrm{N} ; 8^{\circ} 45^{\prime} 2^{\prime \prime} \mathrm{W}$ & Goian & Galicia \\
\hline 8 & Sousa River & $41^{\circ} 5^{\prime} 26^{\prime \prime} \mathrm{N} ; 8^{\circ} 30^{\prime} 39^{\prime \prime} \mathrm{W}$ & Porto & Porto \\
\hline 9 & \multirow{2}{*}{ Tâmega River } & $41^{\circ} 5^{\prime} 50^{\prime \prime} \mathrm{N} ; 8^{\circ} 15^{\prime} 42^{\prime \prime} \mathrm{W}$ & \multirow{2}{*}{ Amarante } & \multirow{2}{*}{ Porto } \\
\hline 10 & & $41^{\circ} 16^{\prime} 8^{\prime \prime} \mathrm{N} ; 8^{\circ} 4^{\prime} 36^{\prime \prime} \mathrm{W}$ & & \\
\hline 11 & \multirow{3}{*}{ Ria de Aveiro Lagoon } & $40^{\circ} 37^{\prime} 32^{\prime \prime} \mathrm{N} ; 8^{\circ} 44^{\prime} 18^{\prime \prime} \mathrm{W}$ & Aveiro & Aveiro \\
\hline 12 & & $40^{\circ} 36^{\prime} 52^{\prime \prime} \mathrm{N} ; 8^{\circ} 44^{\prime} 53^{\prime \prime} \mathrm{W}$ & Aveiro & Aveiro \\
\hline 13 & & $40^{\circ} 39^{\prime} 38^{\prime \prime} \mathrm{N} ; 8^{\circ} 43^{\prime} 50^{\prime \prime} \mathrm{W}$ & Aveiro & Aveiro \\
\hline 14 & \multirow{3}{*}{ Leça River } & $41^{\circ} 12^{\prime} 52^{\prime \prime} \mathrm{N} ; 8^{\circ} 40^{\prime} 5^{\prime \prime} \mathrm{W}$ & \multirow{3}{*}{ Leça } & \multirow{3}{*}{ Porto } \\
\hline 15 & & $41^{\circ} 13^{\prime} 5^{\prime \prime} \mathrm{N} ; 8^{\circ} 37^{\prime} 27^{\prime \prime} \mathrm{W}$ & & \\
\hline 16 & & $41^{\circ} 12^{\prime} 5^{\prime \prime} \mathrm{N} ; 8^{\circ} 36^{\prime} 03^{\prime \prime} \mathrm{W}$ & & \\
\hline 17 & Cabrum River & $41^{\circ} 5^{\prime} 51^{\prime \prime} \mathrm{N} ; 8^{\circ} 2^{\prime} 12^{\prime \prime} \mathrm{W}$ & Resende & Viseu \\
\hline 18 & Moscoso Stream & $40^{\circ} 49^{\prime} 18^{\prime \prime} \mathrm{N} ; 8^{\circ} 24^{\prime} 8^{\prime \prime} \mathrm{W}$ & Aveiro & Aveiro \\
\hline 19 & Caima River & $40^{\circ} 49^{\prime} 59^{\prime \prime} \mathrm{N} ; 8^{\circ} 23^{\prime} 30^{\prime \prime} \mathrm{W}$ & Vale de Cambra & Aveiro \\
\hline 20 & Ave River & $41^{\circ} 20^{\prime} 57^{\prime \prime} \mathrm{N} ; 8^{\circ} 31^{\prime} 13^{\prime \prime} \mathrm{W}$ & Lousado & Braga \\
\hline
\end{tabular}

Figure 1. Schematic localization of the twenty sampling points of the surface water samples collected. 


\subsubsection{Optimization of the SPME Process}

Before the sample's analysis, the optimization of the SPME process was carried out. Variables affecting the process of adsorption to the fiber and the extraction, namely, ionic strength $(0,0.05,0.1$ and $0.2 \%$ of $\mathrm{NaCl})$, desorption temperature $\left(250,260\right.$ and $\left.270{ }^{\circ} \mathrm{C}\right)$, organic solvent $(0,2.5,5.0$ and $7.5 \%$ methanol), extraction time $(15,30,45$ and $60 \mathrm{~min})$ and extraction temperature $\left(20^{\circ} \mathrm{C}, 38^{\circ} \mathrm{C}\right.$ and $\left.60^{\circ} \mathrm{C}\right)$ were evaluated.

\subsection{Gas Chromatography}

Gas chromatograph-ion trap mass spectrometer (Thermo Trace-Ultra GC from Thermo Fisher Scientific (Waltham, MA, USA)) equipped with a fused-silica capillary column ZBXLB (30 m $\times 0.25 \mathrm{~mm}$ ID, $0.25 \mu \mathrm{m}$ film thickness, Phenomenex) was used for the separation of the study pesticides, using helium $99.99 \%$ as carrier gas at a $1.3 \mathrm{~mL} / \mathrm{min}$ flow rate. Injector mode was split/spitless injector in the split mode (split/ratio 10) at $260{ }^{\circ} \mathrm{C}$ during the chromatographic run. The oven temperature was as followed: Initial oven temperature was held at $60^{\circ} \mathrm{C}$ for $1 \mathrm{~min}$, programmed with a gradient of $20^{\circ} \mathrm{C} / \mathrm{min}$ up to $200{ }^{\circ} \mathrm{C}$ where it stays for $1 \mathrm{~min}$ and then an increase of $5^{\circ} \mathrm{C} / \mathrm{min}$ up to $245^{\circ} \mathrm{C}$ where it stays for $32 \mathrm{~min}$. The mass detector conditions were: Transfer line temperature $250{ }^{\circ} \mathrm{C}$, ion source temperature $250^{\circ} \mathrm{C}$, and ionization mode electron impact at $70 \mathrm{eV}$. The retention times were determined in the full scan mode and validation study in the selected ion monitoring (SIM) mode. In SIM mode, the main ions (Q1, Q2, and Q3) were selected for each analyte (Table 1). A matrix-matched calibration curve (using a residue-free surface water sample) was performed using nine concentration levels (10, 50, 100, 500, 1000, $1500,2000,2500$, and $3000 \mathrm{ng} / \mathrm{L}$ ). The addition of the IS, atrazine D-5, was performed at $1000 \mathrm{ng} / \mathrm{L}$. The limits of detection (LOD) and quantification (LOQ) of the method were evaluated considering a signal-to-noise ratio of 3 and 10, respectively. Each concentration was measured twice. Precision was evaluated by calculating the relative standard deviation (RSD) from 3 replicates.

Table 1. GC-IT/MS parameters for each study pesticide.

\begin{tabular}{|c|c|c|c|}
\hline Compounds * & $\begin{array}{l}\text { Time Retention } \\
\text { (min) }\end{array}$ & $\begin{array}{l}\text { SIM Ions (Q1, Q2 and Q3) } \\
\qquad(\mathrm{m} / \mathrm{z})\end{array}$ & GC Segment (min) \\
\hline$\alpha-\mathrm{HCH}$ & 9.66 & $181,219,109$ & $8.50-9.90$ \\
\hline HCB & 9.82 & $284,142,249$ & $8.50-9.90$ \\
\hline diazinon & 10.04 & $179,199,304$ & $9.90-10.20$ \\
\hline$\beta-\mathrm{HCH}$ & 10.36 & $181,219,109$ & $10.20-11.20$ \\
\hline lindane & 11.04 & $181,219,109$ & $10.20-11.20$ \\
\hline vinclozolin & 11.38 & $212,124,187$ & $11.20-11.85$ \\
\hline aldrin & 12.47 & $263,293,66$ & $11.85-13.00$ \\
\hline$\alpha$-endosulfan & 14.89 & $241,195,209$ & $14.10-15.00$ \\
\hline$p, p^{\prime}-\mathrm{DDE}$ & 15.54 & $246,176,318$ & $15.00-16.00$ \\
\hline dieldrin & 15.68 & $79,263,277$ & $15.00-16.00$ \\
\hline endrin & 16.35 & $244,263,317$ & $16.00-17.00$ \\
\hline $0, p^{\prime}-\mathrm{DDT}$ & 16.74 & $235,165,81$ & $16.00-17.00$ \\
\hline$p, p^{\prime}-\mathrm{DDD}$ & 17.21 & $235,165,199$ & $17.00-18.00$ \\
\hline$\beta$-endosulfan & 17.30 & $195,335,339$ & $17.00-18.00$ \\
\hline bifenthrin & 19.51 & $165,166,141$ & $18.00-24.00$ \\
\hline methoxychlor & 20.19 & $227,152,165$ & $18.00-24.00$ \\
\hline iprodione & 20.32 & 187,244 & $18.00-24.00$ \\
\hline cypermethrin & $31.72,31.98,32.44$ & $163,181,91$ & $24.00-35.00$ \\
\hline fenvalerate & $38.59,40.63$ & $125,167,419$ & $35.00-43.00$ \\
\hline deltamethrin & 46.62 & 181,253 & $43.00-50.00$ \\
\hline
\end{tabular}

* pesticides in the table organized by their retention time. 


\section{Results and Discussion}

\subsection{Optimization of the SPME Procedure}

\subsubsection{Ionic Strength Adjustments}

The effect of the amount of salt influenced the extraction efficiency of some analytes present in water samples. All the chemical families presented a good performance without the use of $\mathrm{NaCl}$ (Figure 2A). A few compounds ( $\mathrm{HCH}$ isomers and diazinon) showed higher areas with the addition of $0.2 \% \mathrm{NaCl}$. This may be related to the increase in the ionic strength of the matrix and consequently decreases the solubility of these compounds in water. However, the results showed that the salt aggregate does not help in most of the studied compounds.
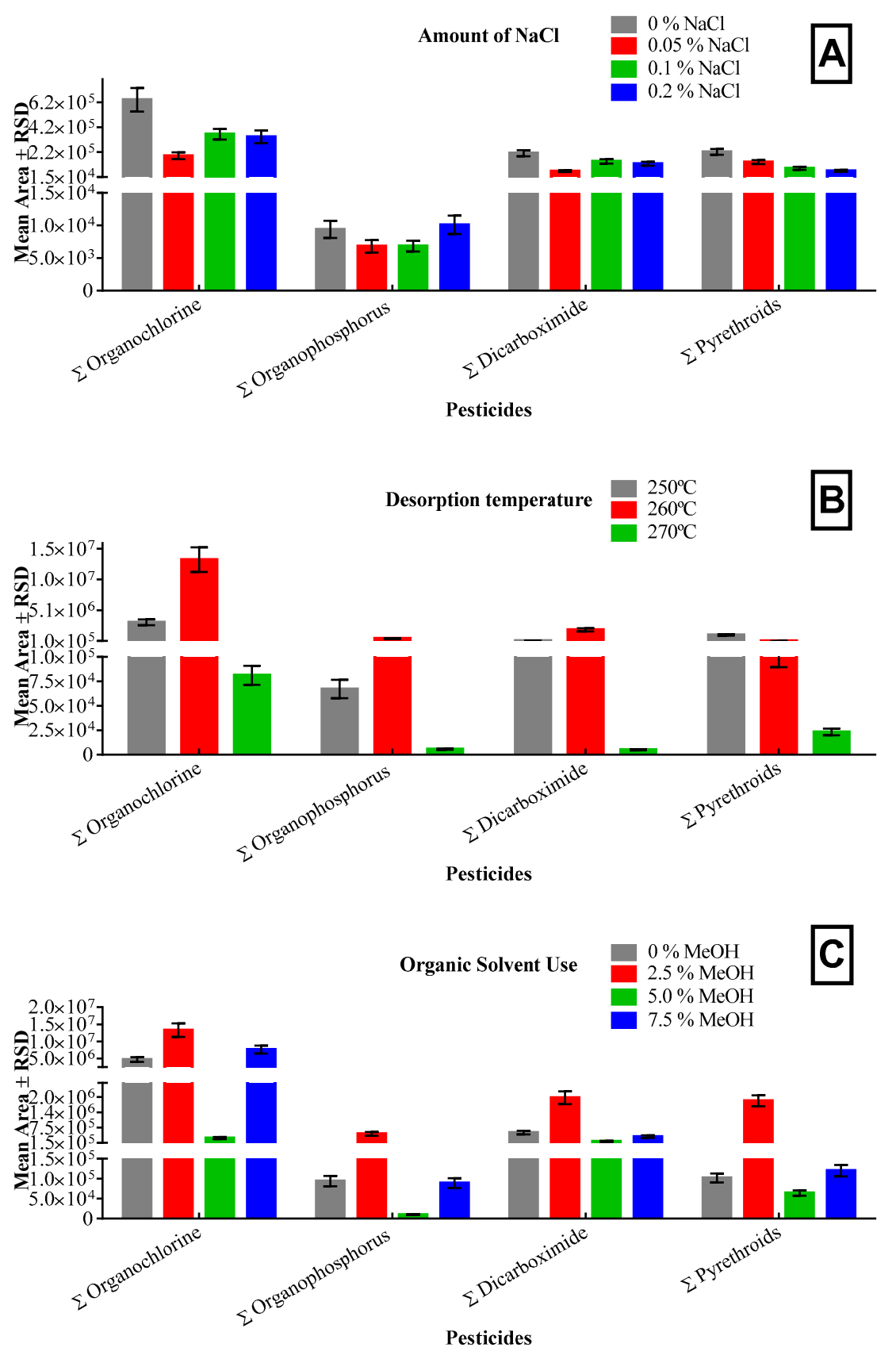

Figure 2. Cont. 

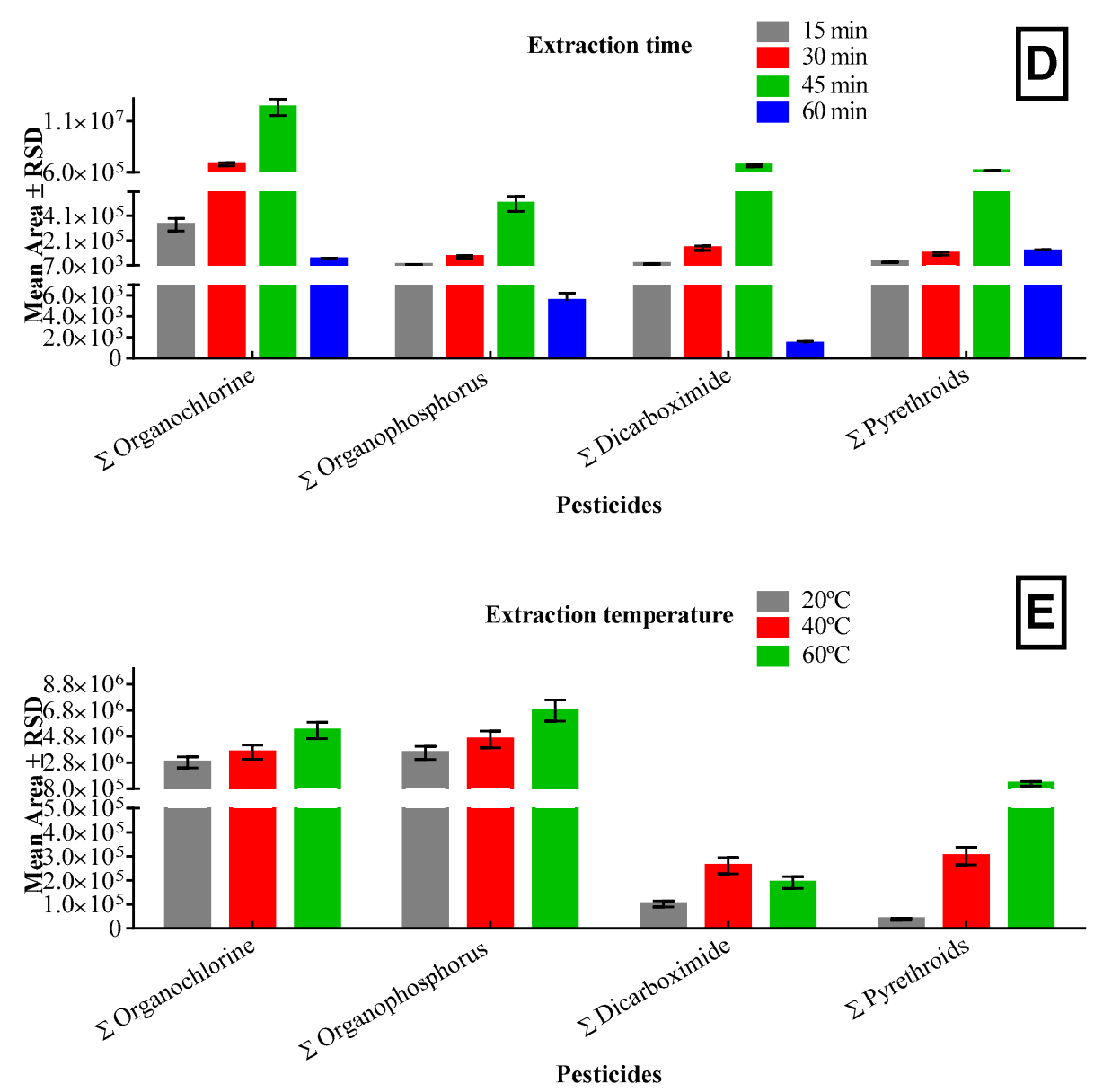

Figure 2. Plot of the areas from each pesticide with: (A) The addiction of $\mathrm{NaCl}$ at $0.00 \%, 0.05 \%, 0.10 \%$, and $0.20 \%$; (B) desorption temperature at $250{ }^{\circ} \mathrm{C}, 260{ }^{\circ} \mathrm{C}$, and $270{ }^{\circ} \mathrm{C}$; (C) the use of organic solvent (MEOH) at $0 \%, 2.5 \%, 5.0 \%$ and $7.5 \%$; (D) extraction time of $15 \mathrm{~min}, 30 \mathrm{~min}, 45 \mathrm{~min}$, and $60 \mathrm{~min}$; (E) extraction temperature of $20^{\circ} \mathrm{C}, 40^{\circ} \mathrm{C}$ and $60^{\circ} \mathrm{C}$.

\subsubsection{Desorption Temperature}

Figure 2B showed the best results for the complete desorption of most pesticides with the desorption temperature at $260^{\circ} \mathrm{C}$. Bifenthrin and iprodione presented complete desorption with a temperature of $250^{\circ} \mathrm{C}$.

\subsubsection{Organic Solvent}

The effect of organic solvent was evaluated, and the addition of $2.5 \%$ methanol improved the extraction efficiency of the target compounds. The effect of this parameter is well demonstrated in Figure 2C.

\subsubsection{Extraction Temperature and Time}

In terms of extraction time, the results showed that as the time increased up to $45 \mathrm{~min}$, the extraction efficiency improved. However, for longer times $(60 \mathrm{~min})$, the performance of the methodology decreased (Figure 2D,E). The results obtained for the extraction temperature study showed similar behavior to the extraction time. As the temperature was increased, better areas were obtained. Only the dicarboximide pesticides had an opposite behavior at $60^{\circ} \mathrm{C}$.

The best conditions were selected, and the extractions were performed in glass vials by immersing the SPME fiber (PDMS) in $10 \mathrm{~mL}$ of water sample with $2.5 \%$ methanol, 
$\mathrm{pH} 3.5$, and placed in the stir plate $(700 \mathrm{rpm})$ for $45 \mathrm{~min}$ at $60^{\circ} \mathrm{C}$. Finally, the desorption temperature selected was $260^{\circ} \mathrm{C}$.

\subsection{Method Validation}

After the optimization of the methodology, the validation study was performed. The proposed method measured different families of pesticides (OCs, PYR, OPs, and dicarboximide). Also, the methodology showed good performance, and the analytical parameters obtained at optimized conditions were calculated and presented in Table 2. Good linear regressions ( $R^{2} \geq 0.9904$ in all cases) were obtained over the tested analytical range. The method achieved LODs and LOQs between $0.2-150 \mathrm{ng} / \mathrm{L}$ and $0.6-450 \mathrm{ng} / \mathrm{L}$, respectively. The precision was evaluated, and the relative standard deviation (RSD) was lower than $15 \%$ is acceptable for all the studied analytes. The validation parameters obtained are in the same order as those reported for other authors applying SPME [19].

Table 2. Coefficient of determination, LOD, and LOQ, of 20 standard pesticides obtained by GC-MS method.

\begin{tabular}{|c|c|c|c|c|}
\hline Groups & Pesticides & $\begin{array}{l}\text { Coefficient of } \\
\text { Determination }\end{array}$ & LOD ng/L & LOQ ng/L \\
\hline \multirow{13}{*}{ Organochlorines } & $\alpha-\mathrm{HCH}$ & 0.9912 & 25.0 & 75.0 \\
\hline & $\beta-\mathrm{HCH}$ & 0.9991 & 60.0 & 180.0 \\
\hline & Lindane & 0.9991 & 75.0 & 225.0 \\
\hline & HCB & 0.9978 & 2.5 & 7.5 \\
\hline & aldrin & 0.9983 & 2.4 & 7.2 \\
\hline & dieldrin & 0.9976 & 0.7 & 2.1 \\
\hline & endrin & 0.9978 & 12.0 & 36.0 \\
\hline & $p, p^{\prime}-\mathrm{DDE}$ & 0.9957 & 0.3 & 0.9 \\
\hline & $0, p^{\prime}$-DDT & 0.9904 & 1.8 & 5.4 \\
\hline & $p, p^{\prime}-\mathrm{DDD}$ & 0.9935 & 5.3 & 15.9 \\
\hline & $\alpha$-endosulfan & 0.9991 & 5.9 & 17.7 \\
\hline & $\beta$-endosulfan & 0.9977 & 3.0 & 9.0 \\
\hline & metoxyclhor & 0.9923 & 1.6 & 4.8 \\
\hline \multirow{4}{*}{ Pyrethroids } & bifenthrin & 0.9925 & 7.0 & 21.0 \\
\hline & cypermethrin & 0.9976 & 30.0 & 900.0 \\
\hline & fenvalerate & 0.9917 & 3.3 & 9.9 \\
\hline & deltamethrin & 0.9939 & 150.0 & 450.0 \\
\hline Organophosphorus & diazinon & 0.9990 & 3.1 & 9.3 \\
\hline \multirow{2}{*}{ Dicarboximide } & Iprodione & 0.9990 & 27.3 & 91.0 \\
\hline & vinclozolin & 0.9994 & 0.2 & 0.6 \\
\hline
\end{tabular}

3.3. Monitoring of 20 Known or Suspected Endocrine-Disrupting Pesticides in Portuguese Surface Water Samples

The national and international authorities and the scientific community have shown interest and concern on the topic of water pollution and its adverse implications for humans and the ecosystem.

The literature has recently reported the presence of several priority pesticides, most of them classified as EDPs in aquatic environments [24,34-36,38,48,49]. Table 3 summarizes the results obtained in the present study with 20 surface water samples in terms of frequency of detection, minimum, maximum, and mean values detected. As the values obtained are different in terms of range, the graphs below show the data distribution by samples and each compound. All the data, including the value below LOQ (estimated by the analytical value), were counted for the data analysis. 
Table 3. A summary of the results obtained in the 20 samples.

\begin{tabular}{|c|c|c|c|c|c|}
\hline Group & Compounds & Frequency (\%) & Min ng/L & Max ng/L & Mean ng/L \\
\hline \multirow{6}{*}{ Organochlorines } & $\Sigma(\alpha-\mathrm{HCH}+\beta-\mathrm{HCH}+$ lindane $)$ & 30 & $<\mathrm{LOQ}$ & 1800 & 460 \\
\hline & $\mathrm{HCB}$ & 45 & $<\mathrm{LOQ}$ & 912 & 201 \\
\hline & $\Sigma($ aldrin + dieldrin + endrin $)$ & 45 & 10 & 430 & 142 \\
\hline & $\Sigma\left(p, p^{\prime}-\mathrm{DDE}+o, p^{\prime}-\mathrm{DDT}+p, p^{\prime}-\mathrm{DDD}\right)$ & 40 & $<\mathrm{LOQ}$ & 70 & 63 \\
\hline & $\Sigma(\alpha$-endosulfan $+\beta$-endosulfan $)$ & 75 & $<\mathrm{LOQ}$ & 30 & 11 \\
\hline & methoxychlor & 5 & nd & 31 & 31 \\
\hline \multirow{4}{*}{ Pyrethroids } & bifenthrin & 10 & nd & $<$ LOQ & - \\
\hline & cypermethrin & 55 & $<\mathrm{LOQ}$ & 351 & 261 \\
\hline & fenvalerate & 10 & 10 & 294 & 150 \\
\hline & deltamethrin & 5 & nd & $<\mathrm{LOQ}$ & - \\
\hline Dicarboximide & vinclozolin & 45 & 20 & 62 & 43 \\
\hline
\end{tabular}

Regarding the 20 spot surface water samples, only the diazinon and iprodione were not detected in the analyzed samples. The $\alpha$ - and $\beta$-endosulfan were the most detected EDPs $(75 \%)$, and the methoxychlor (5\%) and deltamethrin (5\%) were the least detected. Although the samples were collected in different seasons, no significant differences were observed. Even so, pyrethroids were more detected in the summer samples.

\subsubsection{Organochlorine Pesticides in Surface Water Samples}

Several decades after the OCs were banned, they are frequently detected in different environmental samples, due to their persistence and bioaccumulation. These compounds are in continuous movement between the different environmental compartments, such as water, soil, sediments, air, and/or bioconcentrate, in the living organisms [50]. Figure 3 shows a plot with the concentrations detected of each OCs by sample. The values.

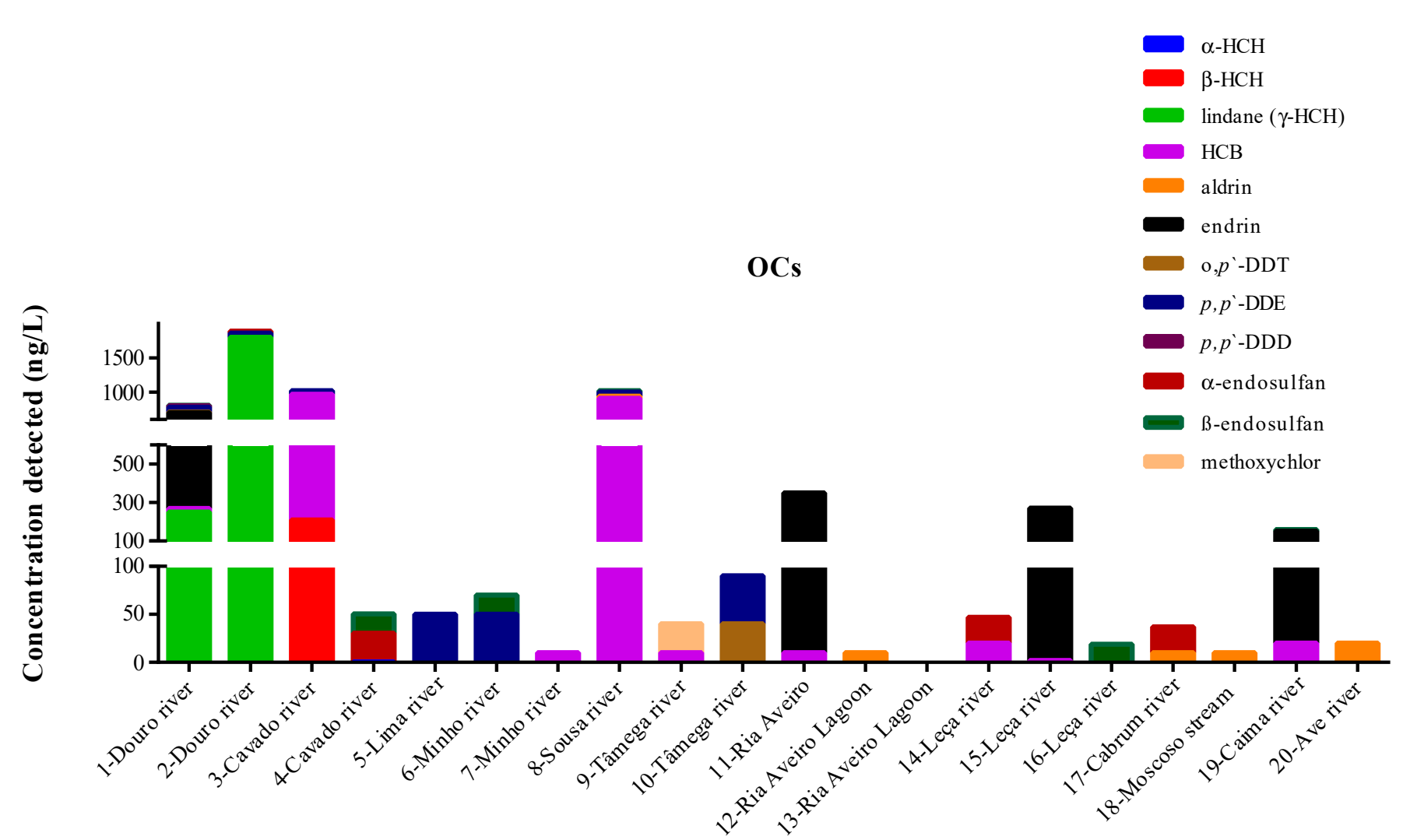

Figure 3. Concentration in ng/L of OCs detected in the 20 surface water samples. 
The highest individual mean value was found for $\mathrm{HCH}$ isomers in the Douro River (Mean $\sum \mathrm{HCH}=2150 \mathrm{ng} / \mathrm{L}$ ) and Cávado River (Mean $\sum \mathrm{HCH}=350 \mathrm{ng} / \mathrm{L}$ ). Indeed, the cumulative values were always above the maximum allowable concentrationEnvironmental Quality Standards (MAC-EQS) established by the Directive 98/83/EC and 2013/39/EU [15,16]. HCHs isomers were also detected in the Minho and Sousa Rivers, but below the quantification limit (<LOQ). The organochlorine compound, HCB, presented concentrations 18.2-fold above the MAC-EQS (50 ng/L) in the Cávado River (760 ng/L) and Sousa River (910 ng/L) (Figure 3). The presence of HCB in other samples was quantified below the MAC-EQS (Rivers: Douro $(20 \mu \mathrm{g} / \mathrm{L})$, Minho $(10 \mu \mathrm{g} / \mathrm{L})$, Tâmega $(10 \mathrm{ng} / \mathrm{L})$, Leça (20 and $2 \mathrm{ng} / \mathrm{L})$, Caima (20 ng/L); Lagoon: Ria Aveiro (10 ng/L)). Endrin was detected above the average annual amounts allowed for surface waters (AA-EQS $=\Sigma 0.05$ ), in three rivers (Douro (430 ng/L), Leça (271 ng/L), and Caima (132 ng/L), and one lagoon (ria Aveiro (342 ng/L)) samples. The other cyclodiene pesticide, aldrin, was detected below the AA-EQS in the three rivers (Sousa (32 ng/L), Cabrum $(10 \mathrm{ng} / \mathrm{L})$, Ave (22 ng/L)), and one stream (Moscoso (12 $\mathrm{ng} / \mathrm{L})$. The same behavior was observed with DDT isomers $\left(\sum p, p^{\prime}\right.$-DDT $+p, p^{\prime}$-DDE $+p, p^{\prime}$-DDD) pesticides analyzed in this work. The sum of the concentration in rivers (Douro $\left(\sum=130 \mathrm{ng} / \mathrm{L}\right)$, Cávado $\left(\sum=53 \mathrm{ng} / \mathrm{L}\right)$, Lima $\left(\sum=50 \mathrm{ng} / \mathrm{L}\right)$, Minho $\left(\sum=54 \mathrm{ng} / \mathrm{L}\right)$, Sousa $\left(\sum=62 \mathrm{ng} / \mathrm{L}\right)$, and Tâmega $\left.\left(\sum=90 \mathrm{ng} / \mathrm{L}\right)\right)$ achieved amounts above the AA-EQS $\left(\sum=0.025 \mu \mathrm{g} / \mathrm{L}\right)$. The endosulfan isomers studied were $(\alpha, \beta)$, and the MAC-EQS $=0.01$ was considered for endosulfan. All rivers, except the Lima River, showed the presence of endosulfan isomers. Finally, methoxychlor was observed at a concentration of $33 \mathrm{ng} / \mathrm{L}$ in the Tâmega River. In general, the rivers with the greatest OCs contamination were the Douro, Cávado, and the Sousa Rivers, as shown in Figure 3. Values above MAC-EQS were found in the seven river samples. Figure 4 presents the chromatogram obtained from the Douro and Cávado Rivers samples, demonstrating the confirmation by GC-MS of the presence of OCs.

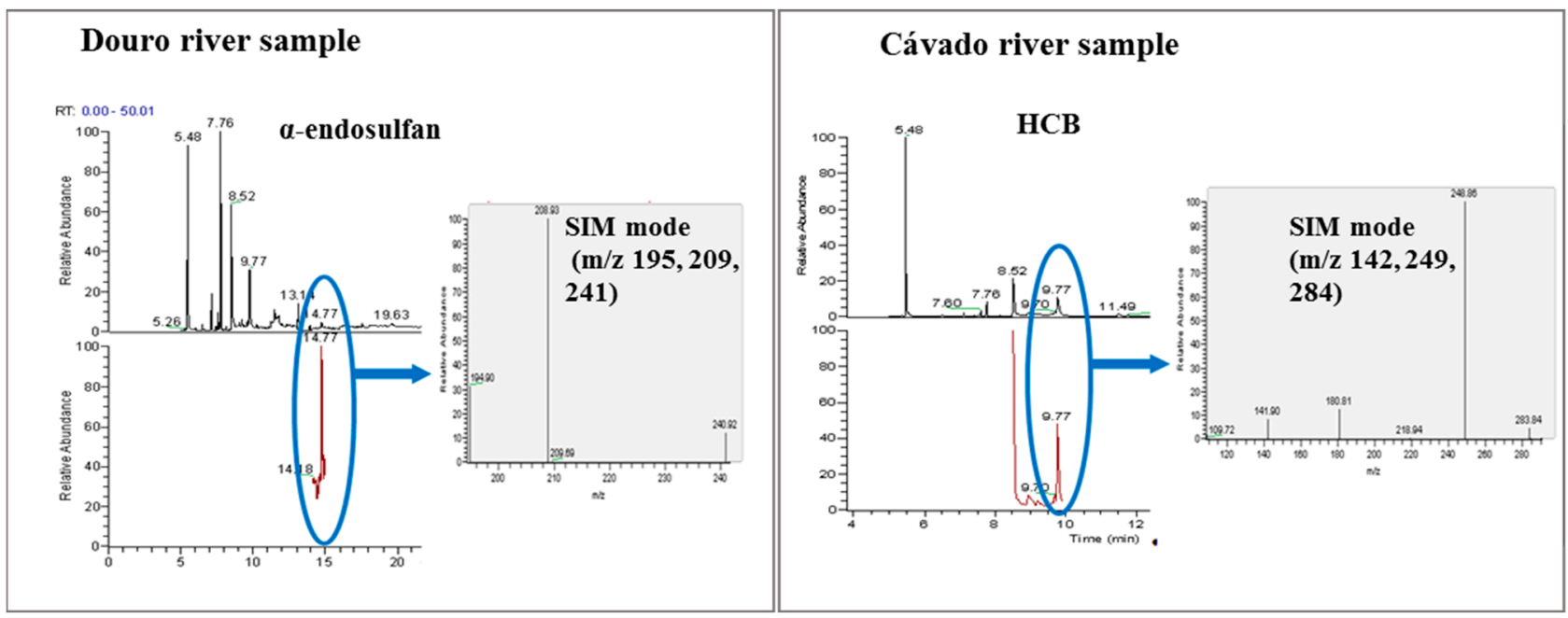

Figure 4. GC-MS chromatograms were obtained in SIM mode and the MS spectrum confirming the detection of HCB and $\alpha$-endosulfan in the Cávado and Douro Rivers, respectively.

Comparing present data with Cruzeiro et al., [37] in Portuguese surface water samples, the $4,4^{\prime}$-DDT and $4,4^{\prime}$-DDD were detected in $100 \%$ of samples analyzed $(\mathrm{N}=20)$, while in the present work, it was $40 \%$. Indeed, the values obtained were above the restrictive European legislation (98/83/EC and 2013/39/EU). The same compound, 4,4'-DDT was quantified in another Portuguese study in concentrations 21.5 fold above the maximum (10 ng/L) level acceptable for inland and surface waters [38]. Although these authors reported HCB levels below its method quantification limit, the opposite occurred in the present work, where these values exceeded the LOQ. In 2017,4,4'-DDT and HCB were also detected in the Douro River estuary, in 8 and 19 samples, respectively, over 2013739/EU 
levels [35]. Some studies reported pollution by these OCs in other samples in Portugal, such as, sediments samples from the Douro River [30,49,51] fruits [26], soil [28,52], and human samples [53]. This study contributes to the continuous evaluation of these compounds and emphasizes the relevance of continuous monitoring studies. Even though the usage of OCs was banned in Portugal, the recorded levels can be a consequence of their persistence or their misuse or illegal use. However, with this work, we can say that its incidence seems to be decreasing, at least for DDT.

\subsubsection{Pyrethroids and Dicarboximide Pesticides in Portuguese Surface Water Samples}

In this study, two PYR (cypermethrin and fenvalerate) and one dicarboximide pesticides (vinclozolin) were detected. Figure 5 shows a plot with the mean concentration in ng/L reported by the sample. Cypermethrin was the most frequently detected, and the Cávado, Cabrum, and Minho Rivers presented higher values. Nevertheless, all the surface water samples showed concentration values above the admissible amounts MAC-EQS. Fenvalerate was detected only in two samples (Cávado and Lima Rivers) at levels of 290 and $100 \mathrm{ng} / \mathrm{L}$, respectively.

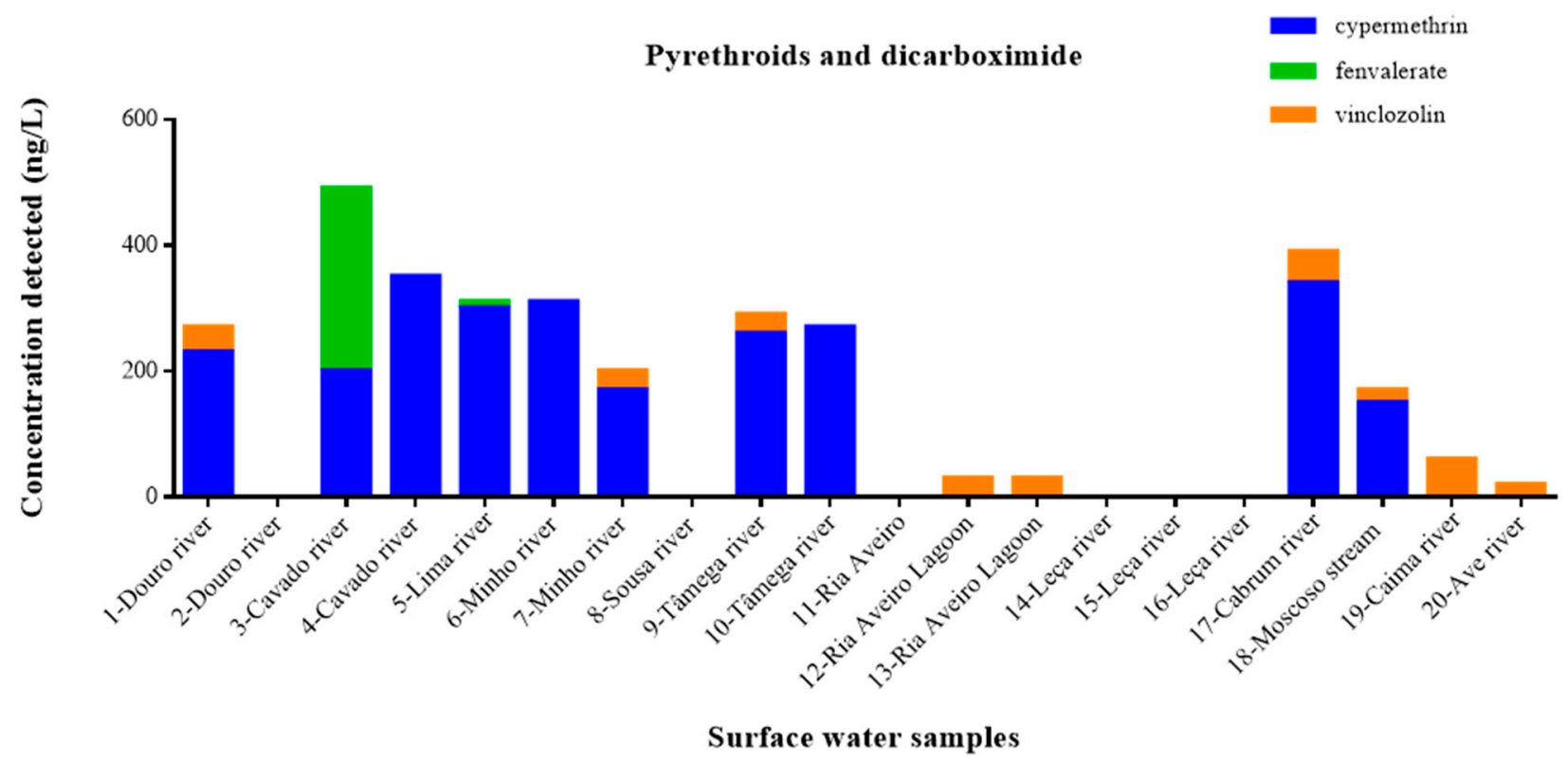

Figure 5. Pyrethroids and dicarboximide pesticides were detected in the 20 surface water samples.

Regarding other studies conducted in Portugal [38], our levels of cypermethrin were slightly lower ( $350 \mathrm{ng} / \mathrm{L}$ ) in terms of environmental levels, compared with a concentration of $453 \mathrm{ng} / \mathrm{L}$ obtained in Ria Formosa lagoon in summer samples. The authors discussed the evidence that the higher concentration presented in samples from the summer period is related to the application of pesticides. In a study conducted in 2017 in the Douro River samples [35], nine samples (in a total of 24 sampling sites) presented concentrations over the limits established by EU, and an average concentration for cypermethrin of $35.9 \mathrm{ng} / \mathrm{L}$. This study has already shown lower values than those detected in samples from the Douro River ( $230 \mathrm{ng} / \mathrm{L}$ ) in the present study. The vinclozolin and iprodione were evaluated in the current work, but only vinclozolin was detected.

Although there is no legislation for this pesticide in surface waters, it was quantified in nine samples: The Douro River (41 ng/L, the Minho River (30 ng/L), the Tâmega River (33 ng/L), Ria Aveiro (32 $\mathrm{\mu g} / \mathrm{L}$ ), the Cabrum river (51 ng/L), the Moscoso Stream (25 ng/L), the Caima River (64 ng/L), and the Ave River (26 ng/L)). The vinclozolin is a fungicide frequently used to control diseases in vineyards [54]. The vineyards in the north region of Portugal are in the hills on the banks of the rivers. The use of this pesticide in agriculture systems may be one of the reasons for the frequent detection. 


\section{Conclusions}

The proposed analytical method, SPME-GC-IT/MS, was firstly optimized for the simultaneous determination of 20 priority pesticides. In terms of analytical validation, the methodology showed good performance and fulfilled the requirements according to European analytical standards to determine the target compounds in water samples. We can conclude that this work stood out for the diversity of sampling sites in Portugal, despite being spot samples. In addition, the surface water samples from several sampling sites from the north end center of Portugal presented known and potential EDPs, with many of them above the established MAC-EQS. The following pesticides were detected in order of decreasing frequency of detection: $\alpha$ - and $\beta$-endosulfan $(75 \%)>$ cypermethrin $(55 \%)>\mathrm{HCB}$, aldrin, dieldrin, endrin, and vinclozolin $(45 \%)>p, p^{\prime}-\mathrm{DDE}+\mathrm{o}, p^{\prime}-\mathrm{DDT}+p, p^{\prime}-\mathrm{DDD}(40 \%)>$ $\mathrm{HCH}$ isomers $(30 \%)$, > fenvalerate $(10 \%)>$ methoxychlor and deltamethrin $(5 \%)$.

The persistence of OCs was again proven, as well as the presence of other pesticides. Despite the legislation established for these samples, this work also concluded that it is still insufficient when the presence of other non-legislated compounds was confirmed.

This study reinforces the data regarding the presence of priority pesticides in the environment and concluded that detected levels are still alarming. The monitoring and control of pesticides in rivers are an important issue that should continue to be explored in many areas and countries, and although the SPME performs well, more automated extraction methods should be explored to decrease the time and the cost of the monitoring analysis.

Supplementary Materials: The following are available online at https:/ /www.mdpi.com/article/10 .3390 /separations8060081/s1, Table S1: List of endocrine-disruptor compounds and their chemistry groups, company supplier, chemical structure, chemical formula, and molar mass.

Author Contributions: All of the authors contributed significantly to the research. Conceptualization, J.V., V.C.F., V.F.D. and C.D.-M.; Formal Analysis, J.V., V.F.D. and V.C.F.; Methodology, J.V., L.C.-S., V.C.F., C.M. and V.F.D.; Investigation, J.V., L.C.-S., V.C.F. and V.F.D.; Resources C.M., C.D.-M. and V.F.D.; Writing - Original Draft Preparation, V.C.F. and J.V.; Writing—Review \& Editing, V.C.F., V.F.D. and C.D.-M.; Visualization, V.C.F., V.F.D. and C.D.-M.; Supervision, V.F.D. and C.D.-M.; Funding Acquisition, C.D.-M. All authors have read and agreed to the published version of the manuscript.

Funding: This work was supported by UID/QUI/50006/2019, UIDB/50006/2020 and UIDP/50006/2020 by the Fundação para a Ciência e a Tecnologia (FCT)/Ministério da Ciência, Tecnologia e Ensino Superior (MCTES) through national funds. Virgínia Cruz Fernandes thanks FCT (Fundação para a Ciência e Tecnologia) and ESF (European Social Fund) through POCH (Programa Operacional Capital Humano) for her PostDoc grant ref. SFRH/BPD/109153/2015. José Vera thanks Erasmus Mundus Program for the Ph.D. grant.

Conflicts of Interest: The authors declare no conflict of interest.

\section{References}

1. Lauretta, R.; Sansone, A.; Sansone, M.; Romanelli, F.; Appetecchia, M. Endocrine Disrupting Chemicals: Effects on Endocrine Glands. Front. Endocrinol. 2019, 10, 178. [CrossRef]

2. Kassotis, C.D.; Vandenberg, L.N.; Demeneix, B.A.; Porta, M.; Slama, R.; Trasande, L. Endocrine-disrupting chemicals: Economic, regulatory, and policy implications. Lancet Diabetes Endocrinol. 2020, 8, 719-730. [CrossRef]

3. Özkara, A.; Akyil, D.; Konuk, M. Pesticides, Environmental Pollution, and Health; InTech: London, UK, 2016.

4. Kabir, E.R.; Rahman, M.S.; Rahman, I. A review on endocrine disruptors and their possible impacts on human health. Environ. Toxicol. Pharmacol. 2015, 40, 241-258. [CrossRef] [PubMed]

5. Pereira, L.C.; de Souza, A.O.; Bernardes, M.F.F.; Pazin, M.; Tasso, M.J.; Pereira, P.H.; Dorta, D.J. A perspective on the potential risks of emerging contaminants to human and environmental health. Environ. Sci. Pollut. Res. 2015, 22, 13800-13823. [CrossRef] [PubMed]

6. Kasonga, T.K.; Coetzee, M.A.A.; Kamika, I.; Ngole-Jeme, V.M.; Benteke Momba, M.N. Endocrine-disruptive chemicals as contaminants of emerging concern in wastewater and surface water: A review. J. Environ. Manag. 2021, 277, 111485. [CrossRef] [PubMed]

7. Jayaraj, R.; Megha, P.; Sreedev, P. Review Article. Organochlorine pesticides, their toxic effects on living organisms and their fate in the environment. Interdiscip. Toxicol. 2016, 9, 90-100. [CrossRef] 
8. Chrustek, A.; Hołyńska-Iwan, I.; Dziembowska, I.; Bogusiewicz, J.; Wróblewski, M.; Cwynar, A.; Olszewska-Słonina, D. Current Research on the Safety of Pyrethroids Used as Insecticides. Medicina 2018, 54, 61. [CrossRef]

9. Lushchak, V.I.; Matviishyn, T.M.; Husak, V.V.; Storey, J.M.; Storey, K.B. Pesticide toxicity: A mechanistic approach. EXCLI J. 2018, 17, 1101-1136. [CrossRef]

10. Sagiv, S.K.; Bruno, J.L.; Baker, J.M.; Palzes, V.; Kogut, K.; Rauch, S.; Gunier, R.; Mora, A.M.; Reiss, A.L.; Eskenazi, B. Prenatal exposure to organophosphate pesticides and functional neuroimaging in adolescents living in proximity to pesticide application. Proc. Natl. Acad. Sci. USA 2019, 116, 18347. [CrossRef] [PubMed]

11. Brander, S.M.; Gabler, M.K.; Fowler, N.L.; Connon, R.E.; Schlenk, D. Pyrethroid pesticides as endocrine disruptors: Molecular mechanisms in vertebrates with a focus on fishes. Environ. Sci. Technol. 2016, 50, 8977-8992. [CrossRef] [PubMed]

12. Nasuti, C.; Carloni, M.; Fedeli, D.; Gabbianelli, R.; Di Stefano, A.; Serafina, C.L.; Silva, I.; Domingues, V.; Ciccocioppo, R. Effects of early life permethrin exposure on spatial working memory and on monoamine levels in different brain areas of pre-senescent rats. Toxicology 2013, 303, 162-168. [CrossRef]

13. Yang, C.; Lim, W.; Song, G. Mediation of oxidative stress toxicity induced by pyrethroid pesticides in fish. Comp. Biochem. Physiol. Part. C Toxicol. Pharmacol. 2020, 234, 108758. [CrossRef]

14. Hecker, M.; Hollert, H. Endocrine Disruptor Screening: Regulatory Perspectives and Needs. Environ. Sci. Eur. 2011, 23, 15. [CrossRef]

15. European Union. Directive 2013/39/EU of the European Parliament and of the Council. Off. J. Eur. Union 2013, 1-17.

16. European Union. Council Directive 98/83/EC of 3 November 1998 on the quality of water intended for human consumption. Off. J. 1998, 32-54.

17. Ouyang, G.; Pawliszyn, J. SPME in environmental analysis. Anal. Bioanal. Chem. 2006, 386, 1059-1073. [CrossRef] [PubMed]

18. Albaseer, S.S.; Nageswara Rao, R.; Swamy, Y.V.; Mukkanti, K. An overview of sample preparation and extraction of synthetic pyrethroids from water, sediment and soil. J. Chromatogr. A 2010, 1217, 5537-5554. [CrossRef] [PubMed]

19. Merkle, S.; Kleeberg, K.; Fritsche, J. Recent Developments and Applications of Solid Phase Microextraction (SPME) in Food and Environmental Analysis-A Review. Chromatography 2015, 2, 293-381. [CrossRef]

20. Locatelli, M.; Sciascia, F.; Cifelli, R.; Malatesta, L.; Bruni, P.; Croce, F. Analytical methods for the endocrine disruptor compounds determination in environmental water samples. J. Chromatogr. A 2016, 1434, 1-18. [CrossRef]

21. Alam, M.N.; Pawliszyn, J. Effect of Binding Components in Complex Sample Matrices on Recovery in Direct Immersion Solid-Phase Microextraction: Friends or Foe? Anal. Chem. 2018, 90, 2430-2433. [CrossRef] [PubMed]

22. Filho, A.M.; dos Santos, F.N.; Pereira, P.A.d.P. Development, validation and application of a method based on DI-SPME and GC-MS for determination of pesticides of different chemical groups in surface and groundwater samples. Microchem. J. 2010, 96, 139-145. [CrossRef]

23. Jabali, Y.; Millet, M.; El-Hoz, M. Optimization of a DI-SPME-GC-MS/MS method for multi-residue analysis of pesticides in waters. Microchem. J. 2019, 147, 83-92. [CrossRef]

24. Olisah, C.; Adeniji, A.O.; Okoh, O.O.; Okoh, A.I. Occurrence and risk evaluation of organochlorine contaminants in surface water along the course of Swartkops and Sundays River Estuaries, Eastern Cape Province, South Africa. Environ. Geochem. Health 2019, 41, 2777-2801. [CrossRef] [PubMed]

25. Hashmi, T.A.; Qureshi, R.; Tipre, D.; Menon, S. Investigation of pesticide residues in water, sediments and fish samples from Tapi River, India as a case study and its forensic significance. Environ. Forensics 2020, 21, 1-10. [CrossRef]

26. Fernandes, V.C.; Domingues, V.F.; Mateus, N.; Delerue-Matos, C. Organochlorine Pesticide Residues in Strawberries from Integrated Pest Management and Organic Farming. J. Agric. Food Chem. 2011, 59, 7582-7591. [CrossRef]

27. Álvarez-Muñoz, D.; Rodríguez-Mozaz, S.; Jacobs, S.; Serra-Compte, A.; Cáceres, N.; Sioen, I.; Verbeke, W.; Barbosa, V.; Ferrari, F.; Fernández-Tejedor, M.; et al. Pharmaceuticals and endocrine disruptors in raw and cooked seafood from European market: Concentrations and human exposure levels. Environ. Int. 2018, 119, 570-581. [CrossRef]

28. Correia-Sá, L.; Fernandes, V.C.; Carvalho, M.; Calhau, C.; Domingues, V.F.; Delerue-Matos, C. Optimization of QuEChERS method for the analysis of organochlorine pesticides in soils with diverse organic matter. J. Sep. Sci. 2012, 35, 1521-1530. [CrossRef] [PubMed]

29. Rodrigues, C.; Bio, A.; Guimarães, L.; Fernandes, V.C.; Delerue-Matos, C.; Vieira, N. Assessing the ecological status of fluvial ecosystems employing a macroinvertebrate multi-taxon and multi-biomarker approach. Environ. Monit. Assess. 2019, $191,503$. [CrossRef]

30. Carvalho, P.N.; Rodrigues, P.N.R.; Basto, M.C.P.; Vasconcelos, M.T.S.D. Organochlorine pesticides levels in Portuguese coastal areas. Chemosphere 2009, 75, 595-600. [CrossRef]

31. Rodrigues, E.T.; Alpendurada, M.F.; Guimarães, A.; Avó, R.; Ferreira, B.; Pardal, M.A. The environmental condition of an estuarine ecosystem disturbed by pesticides. Environ. Sci. Pollut. Res. 2019, 26, 24075-24087. [CrossRef]

32. Pinto, M.I.; Burrows, H.D.; Sontag, G.; Vale, C.; Noronha, J.P. Priority pesticides in sediments of European coastal lagoons: A review. Mar. Pollut. Bull. 2016, 112, 6-16. [CrossRef]

33. Álvarez-Muñoz, D.; Rodríguez-Mozaz, S.; Maulvault, A.L.; Tediosi, A.; Fernández-Tejedor, M.; van den Heuvel, F.; Kotterman, M.; Marques, A.; Barceló, D. Occurrence of pharmaceuticals and endocrine disrupting compounds in macroalgaes, bivalves, and fish from coastal areas in Europe. Environ. Res. 2015, 143, 56-64. [CrossRef] 
34. Silva, E.; Daam, M.A.; Cerejeira, M.J. Aquatic risk assessment of priority and other river basin specific pesticides in surface waters of Mediterranean river basins. Chemosphere 2015, 135, 394-402. [CrossRef]

35. Cruzeiro, C.; Amaral, S.; Rocha, E.; Rocha, M.J. Determination of 54 pesticides in waters of the Iberian Douro River estuary and risk assessment of environmentally relevant mixtures using theoretical approaches and Artemia salina and Daphnia magna bioassays. Ecotoxicol. Environ. Saf. 2017, 145, 126-134. [CrossRef]

36. Sousa, J.C.G.; Ribeiro, A.R.; Barbosa, M.O.; Ribeiro, C.; Tiritan, M.E.; Pereira, M.F.R.; Silva, A.M.T. Monitoring of the 17 EU Watch List contaminants of emerging concern in the Ave and the Sousa Rivers. Sci. Total Environ. 2019, 649, 1083-1095. [CrossRef] [PubMed]

37. Cruzeiro, C.; Pardal, M.; Rocha, E.; Rocha, M.J. Occurrence and seasonal loads of pesticides in surface water and suspended particulate matter from a wetland of worldwide interest-The Ria Formosa Lagoon, Portugal. Environ. Monit. Assess. 2015, 187, 669. [CrossRef]

38. Cruzeiro, C.; Rocha, E.; Pardal, M.Â.; Rocha, M.J. Uncovering seasonal patterns of 56 pesticides in surface coastal waters of the Ria Formosa lagoon (Portugal), using a GC-MS method. Int. J. Environ. Anal. Chem. 2015, 95, 1370-1384. [CrossRef]

39. Mansilha, C.; Melo, A.; Ferreira, I.M.P.L.V.O.; Pinho, O.; Domingues, V.; Pinho, C.; Gameiro, P. Groundwater from Infiltration Galleries Used for Small Public Water Supply Systems: Contamination with Pesticides and Endocrine Disruptors. Bull. Environ. Contam. Toxicol. 2011, 87, 312-318. [CrossRef] [PubMed]

40. Vieira, M.E.C.; Bordalo, A.A. The Douro estuary (Portugal): A mesotidal salt wedge. Oceanol. Acta 2000, 23, 585-594. [CrossRef]

41. Gomes, A.I.; Pires, J.C.M.; Figueiredo, S.A.; Boaventura, R.A.R. Optimization of River Water Quality Surveys by Multivariate Analysis of Physicochemical, Bacteriological and Ecotoxicological Data. Water Resour. Manag. 2014, 28, 1345-1361. [CrossRef]

42. Costa-Dias, S.; Freitas, V.; Sousa, R.; Antunes, C. Factors influencing epibenthic assemblages in the Minho Estuary (NW Iberian Peninsula). Mar. Pollut. Bull. 2010, 61, 240-246. [CrossRef] [PubMed]

43. Santos, S.; Vilar, V.J.P.; Alves, P.; Boaventura, R.A.R.; Botelho, C. Water quality in Minho/Miño River (Portugal/Spain). Environ. Monit. Assess. 2013, 185, 3269-3281. [CrossRef] [PubMed]

44. Almeida, C.M.R.; Mucha, A.P.; Teresa Vasconcelos, M. Role of different salt marsh plants on metal retention in an urban estuary (Lima estuary, NW Portugal). Estuar. Coast. Shelf Sci. 2011, 91, 243-249. [CrossRef]

45. Alves, C.M.; Boaventura, R.R.A.R.; Soares, H.M.V.M. Evaluation of heavy metals pollution loadings in the sediments of the Ave river basin (Portugal). Soil Sediment. Contam. 2009, 18, 603-618. [CrossRef]

46. Pato, P.; Lopes, C.; Válega, M.; Lillebø, A.I.; Dias, J.M.; Pereira, E.; Duarte, A.C. Mercury fluxes between an impacted coastal lagoon and the Atlantic Ocean. Estuar. Coast. Shelf Sci. 2008, 76, 787-796. [CrossRef]

47. Nunes, M.L.; Ferreira Da Silva, E.; de Almeida, S.F.P. Assessment of water quality in the Caima and Mau River basins (Portugal) using geochemical and biological Indices. Water Air Soil Pollut. 2003, 149, 227-250. [CrossRef]

48. Cruzeiro, C.; Rocha, E.; Pardal, M.Â.; Rocha, M.J. Environmental assessment of pesticides in the Mondego River Estuary (Portugal). Mar. Pollut. Bull. 2016, 103, 240-246. [CrossRef]

49. Waszak, I.; Dabrowska, H.; Komar-Szymczak, K. Comparison of common persistent organic pollutants (POPs) in flounder (Platichthys flesus) from the Vistula (Poland) and Douro (Portugal) River estuaries. Mar. Pollut. Bull. 2014, 81, 225-233. [CrossRef]

50. Yang, D.; Qi, S.; Zhang, J.; Wu, C.; Xing, X. Organochlorine pesticides in soil, water and sediment along the Jinjiang River mainstream to Quanzhou Bay, southeast China. Ecotoxicol. Environ. Saf. 2013, 89, 59-65. [CrossRef] [PubMed]

51. Villaverde, J.; Hildebrandt, A.; Martínez, E.; Lacorte, S.; Morillo, E.; Maqueda, C.; Viana, P.; Barceló, D. Priority pesticides and their degradation products in river sediments from Portugal. Sci. Total Environ. 2008, 390, 507-513. [CrossRef]

52. Fernandes, V.C.; Lehotay, S.J.; Geis-Asteggiante, L.; Kwon, H.; Mol, H.G.; van der Kamp, H.; Mateus, N.; Domingues, V.F.; Delerue-Matos, C. Analysis of pesticide residues in strawberries and soils by GC-MS/MS, LC-MS/MS and two-dimensional GC-time-of-flight MS comparing organic and integrated pest management farming. Food Addit. Contam. Part A Chem. Anal. Control. Expo. Risk Assess. 2014, 31, 262-270. [CrossRef]

53. Pestana, D.; Fernandes, V.; Faria, G.; Sa, C.; Meireles, M.; Monteiro, R.; Domingues, V.; Calhau, C. Persistent organic pollutant (POPs) levels in human visceral and subcutaneous adipose tissue on an obese Portuguese population-Metabolic improvement after bariatric surgery versus POPs burden. Toxicol. Lett. 2011, 205, S75-S76. [CrossRef]

54. Martins, J.; Esteves, C.; Limpo-Faria, A.; Barros, P.; Ribeiro, N.; Simões, T.; Correia, M.; Delerue-Matos, C. Analysis of six fungicides and one acaricide in still and fortified wines using solid-phase microextraction-gas chromatography/tandem mass spectrometry. Food Chem. 2012, 132, 630-636. [CrossRef] 